\title{
A journey through clinical education
}

\author{
D. G. Murray ${ }^{1}$
}

\section{Key points}

\begin{tabular}{|l|l|l|}
\hline Increases awareness of teaching styles. & Discusses the clinical journey and CPD. & Increases knowledge of feedback
\end{tabular}

mechanisms.

Emphasises the importance of reflection.

This opinion piece centres on my own journey through clinical education and reflects on my involvement in clinical undergraduate teaching. Utilising experiences teaching on undergraduate clinics, before and after attending the Advanced Certificate in Clinical Education through the Royal College of Surgeons in Glasgow, I address how the course has allowed me to grow and adapt my teaching style to provide the optimum learning environment for students. Particular emphasis is placed on an andragogical teaching methodology and the importance of intrinsic motivation to allow for further clinical development.

Ernest Hemmingway once said 'It is good to have an end to journey toward; but it is the journey that matters, in the end.' Although, at an early stage of my practising and teaching career, I have been in constant education for over twenty years. During that time, I found it is easy to become so focused on the result that you lose sight of the path which got you there. I have recently been on an educational journey allowing me to critically analyse and reflect on my own educational experiences. In this paper, I will highlight how my approach to clinical education has changed in three key areas: methodology, motivation and feedback.

Education can be simply defined as the process of imparting or acquiring knowledge or skills. The way in which you deliver the information is key if you want the trainee to maximise their understanding and development. On reflection, I was primarily educated, at all levels of education, using a pedagogical methodology and in particular the learning by being told' model described by Bourne et al. ${ }^{1}$ This most definitely has a place where there

'Dental Core Trainee, Glasgow Dental Hospital and School Correspondence to: David Murray Email: david.murray123@nhs.net

Refereed Paper.

Accepted 7 August 2018

Published online 5 October 2018

DOI: $10.1038 /$ sj.bdj.2018.811 is a knowledge deficit between learner and educator that is, primary education. ${ }^{2}$ However, this teaching methodology develops surface learners where the premise is on knowledge regurgitation to pass assessment. I personally remember even in my university years being told by lecturers to remember specific information purely for the purposes of passing an examination. As we are products of our environment I was guilty of teaching using pedagogical methods with information overload and teacher dominated interactions. I have however, evolved my primary teaching method to a more andragogical approach. Andragogy is literally defined as the theory and practice of educating adults. ${ }^{3} \mathrm{I}$ am primarily involved with the clinical teaching of final year undergraduate students. These students have passed their final exit examination and therefore, benefit from an andragogical approach. Emphasis is placed on student directed learning with active discussion and participation to develop key skills critical to their growth as young clinicians. Teaching is based on learner experiences providing an opportunity for individual reflection and critical appraisal. When the student engages with their learning this has proven to be very effective.

What motivates us? This has been a key question which many people more intelligent than I have attempted to answer. However, self or intrinsic motivation, in my opinion, is key to our development as clinicians and therefore, intrinsically motivating our students is one of our primary roles as clinical educators. As someone from a sporting background I always found motivation in this quote from legendary basketball coach John Wooden 'The true test of a man's character is what he does when no one is watching.' This is particularly pertinent to young clinicians across the country as achieving your BDS is merely the first step on the road toward clinical excellence. Once the extrinsic motivating factor of summative assessment has been removed, practising clinicians must be intrinsically motivated and make a lifelong commitment to continuing professional development. This often means investing time and money in yourself to achieve your own personal goals. Continuing professional development is a mindset and it is therefore, critical to educate and motivate our students not just for today but for tomorrow when, to quote John Wooden, 'no one is watching.' As such, I have not only changed my educational style but also my motivational strategy. I now place much greater emphasis on the student and the process rather than the goal. Autonomous motivation defined by personally developed goals and interests was shown to be more effective in achieving positive outcomes compared with extrinsic motivating factors. ${ }^{4}$ This form of motivation has also been shown to be enhanced by positive feedback. ${ }^{5}$ I now 
therefore, ensure each teaching session is of interest and relevant to the needs of the student with student-driven goals and time dedicated to feedback. By implementing this strategy, I believe, I am now utilising the students' intrinsic motivation to achieve their individual goals. My hope is that they will be able to carry this motivation forwards into their practising career as the clinical journey does not stop at graduation.

Feedback is the cornerstone of effective clinical teaching. ${ }^{6}$ There is, therefore, great emphasis being placed on feedback at all levels of training. For example, each year I have to send out a multi-source feedback questionnaire to be completed by my colleagues. This creates a formal document of feedback which I then submit at my annual review. I am in no doubt that this process increases the quantity of feedback but it does not necessarily improve the quality of feedback. I have received feedback which has been invaluable to my development and feedback which has had no benefit whatsoever. Generic terms such as 'good performance', 'great work' or 'could do better' have not been specific enough to aid my own development. Although I have always tried to avoid using generic terms and clichés when providing feedback, I was guilty of leading the discussion and not giving students sufficient opportunity to show any level of insight into their performance. The purpose of giving feedback is to encourage learners to think about their performance and how they might improve. ${ }^{7}$ Surveys of learners' preferences show that they want feedback that stimulates them to reflect on what they are doing. ${ }^{8}$ As a result, I have used Pendleton's model as my primary feedback method. I have found this establishes a conversation around the task and allows the trainee to demonstrate insight into their own performance. It also facilitates discussion around both the good and bad points allowing for positive reinforcement and the development of strategies to narrow the gap between actual and desired performance. This has been well received by my students and has given me greater confidence when providing performance based feedback.

Reflection is key to any practitioner and educator. Although, relatively young in my practising career I am passionate about teaching and improving the standard of clinical care. Initially, I was raw, a product of my environment using skills developed and modelled on my own experiences within education. I have since reflected on my own educating style utilising new knowledge and techniques to provide a better environment for my students to grow and develop. This has been a great journey for me educationally, and is certainly one far from completion; which is not a bad thing, and Ernest Hemmingway's words ring true as I reflect on them too.

1. Bourne J R, McMaster E, Rieger J, Campbell J O. Paradigms for online learning: a case study in the design and implementation of an asynchronous learning networks course. J Asynchr Learn Net 1997; 1: 1-9.

2. Moyles J, Adams S, Study of Pedagogical Effectiveness in Early Learning. 2002. Available at http://dera.ioe. ac.uk/4591/1/RR363.pdf (accessed September 2018).

3. Brookfield S D. Understanding and Facilitating Adult Learning. A comprehensive analysis of principles and effective practice. Milton Keynes: Open University Press, 1986.

4. Sheldon K M, Elliot A J. Not all personal goals are personal: Comparing autonomous and controlled reasons as predictors of effort and attainment. Person Soc Psychol Bull 1998; 24: 546-557.

5. Deci E, Ryan R. A motivational approach to self: Integration in personality. In R. Dienstbier (Ed.), Nebraska symposium on motivation: Vol. 38. Perspectives on motivation. pp. 237-288. Lincoln: University of Nebraska Press, 1991.

6. Hesketh E A, Laidlaw J M. Developing the teaching instinct: 1: feedback. Med Teach 2002; 24: 245-248.

7. Liberman A S, Liberman M, Steinert Y, McLeod P, Meterissian $S$. Surgery residents and attending surgeons have different perceptions of feedback. Med Teach 2005; 27: 470-477.

8. Rees C, Shepherd M. Students' and assessors' attitudes towards students' self-assessment of their personal and professional behaviours. Med Educ 2005; 39: 30-39. 